\title{
CES1 Gene
}

National Cancer Institute

\section{Source}

National Cancer Institute. CES1 Gene. NCI Thesaurus. Code C116034.

This gene plays a role in the hydrolysis of aromatic and aliphatic esters. 